This is the accepted manuscript version of the journal article, published in Journal of Applied Phycology, which is made available for scholarly purposes only, in accordance with the journal's author permissions. The final authenticated version is available online at: https://doi.org/[ 10.1007/s10811-018-1512-4 ]".

\title{
The inhibition of anaerobic digestion by model phenolic compounds representative of those from Sargassum muticum
}

\author{
John J Milledge ${ }^{1 *}$, Birthe V Nielsen ${ }^{1}$ and Patricia J Harvey ${ }^{1}$ \\ ${ }^{1}$ University of Greenwich, Algae Biotechnology Research Group, Faculty of Engineering \\ and Science, Central Avenue, Chatham Maritime, Kent, ME4 4TB
}

*Corresponding author j.j.milledge@gre.ac.uk 


\section{Abstract}

2 Practical yields of biogas from the anaerobic digestion of macroalgae, and Sargassum

3 muticum in particular, are substantially below the theoretical maximum. There is considerable

4 conjecture about the reasons for the relatively low practical methane yields from seaweed and

5 polyphenols are suggested as one of the elements in the low yield of methane from brown

6 seaweeds. However, there appears to be little information on the effect of specific phenolics

7 on defined substrates.

8 This paper examines the effect of some simple phenolic compounds, representative of those

9 reported in Sargassum muticum, on methane production from a range of model substrates.

10 Three simple phenolics were selected, gallic acid, epicatechin and phloroglucinol; at four

11 addition levels, $0,0.5,3.5$ and $7.5 \% \mathrm{w} / \mathrm{w}$ of substrate; for four substrates, a readily digested

12 simple organic substance, glycerol, and three polymers found in seaweed, cellulose, alginic

13 acid and the sodium salt of alginic acid.

14 Alginic acid and its sodium salt were found to be recalcitrant with average methane yields 15 equivalent to only $23 \%$ - $28 \%$ of their theoretical methane potential. Methane yield was further reduced by the presence of high concentrations ( $7 \%$ of substrate equivalent to $17.5 \mathrm{mg}$ $\mathrm{L}^{-1}$ ) of phloroglucinol and epicatechin. None of the phenolic compounds studied appeared to inhibit the breakdown of the simple and readily digested compound, glycerol. Low methane yield in seaweed may be due to the recalcitrance of complex hydrocolloids and phenolic inhibition of the breakdown of more complex molecules in the initial hydrolysis stage of anaerobic digestion, but further research is required.

\section{Keywords}

anaerobic digestion; polyphenols; gallic acid; phloroglucinol; epicatechin; seaweed; algae; macroalgae; Sargassum muticum; Phaeophyta; Japanese wireweed 
27 Abbreviations

28 AD

29 Ave

30 MP

$31 \mathrm{dw}$

32 SD

33 VS

34 wt

35

36
Anaerobic Digestion

Average

Methane Potential

Dry Weight

Standard Deviation

Volatile Solids

Weight 
Seaweeds are considered as among the most potentially significant future sources of sustainable biofuels. Unlike terrestrial crops cultivated for biofuel, many algae species grow in brackish or salt water avoiding competition for agricultural land and fresh water required for food production (Menetrez 2012; Dijk and Schoot 2015; Barbot et al. 2016; Milledge and Harvey 2016b). Sargassum muticum is a brown seaweed that is an invasive species to Europe. Attempts to eradicate S. muticum have failed (Josefsson and Jansson 2011), and methods are being researched for its valorisation to encourage harvesting and control (Balboa et al. 2015; Milledge et al. 2015a). S. muticum has been suggested as a source of biochemicals, nutraceuticals and pharmaceuticals (Milledge et al. 2015a; Rodrigues et al. 2015); a biorefinery feedstock (Balboa et al. 2015); and a biofuel feedstock (Milledge et al. 2015b; Soto et al. 2015b; Milledge and Harvey 2016a).

Anaerobic digestion (AD) is generally the process of choice for energy production from high water content biomass, and biogas produced from $\mathrm{AD}$ is being used to make the most of a number of biomass wastes by turning them into renewable energy (Weiland 2010; Barbot et al. 2016). It is a safe and cost-effective way to dispose of unwanted organic waste, and for this reason a favoured solution for industry and governments (Cave 2013; Lou et al. 2013; Nguyen et al. 2014; Linville et al. 2015).

Seaweed was used as a feedstock for industrial production of biogas using AD in the 19th century (Biomara 2014; Discover Tiree 2014), and seaweed as feedstock for AD has been, and is, the subject of considerable of research (Lewis et al. 2011; Milledge et al. 2014; Ward et al. 2014; Centre for Process Innovation (CPI) 2016). Although various groups assessing the suitability of seaweed AD generally found that seaweeds were mostly a suitable biomass for AD (Sutherland and Varela 2014), practical yields of biogas from the AD of macroalgae are considerably below the theoretical maximum. The typical methane yield from seaweed of $\sim 0.2 \mathrm{~m}^{3} \mathrm{CH}_{4} \mathrm{~g}^{-1} \mathrm{VS}$ (Alvarado-Morales et al. 2013; Chen et al. 2015) is $<50 \%$ of that from common commercially exploited feedstocks (Golueke et al. 1957; Nallathambi Gunaseelan 1997; Banks and Zhang 2010; Nguyen et al. 2014; Astals et al. 2015). The methane potential of Sargassum muticum is also low at $\sim 0.13 \mathrm{~L} \mathrm{CH}_{4} \mathrm{~g}^{-1}$ VS less than $27 \%$ of theoretical maximum methane yield (Jard et al. 2013; Soto et al. 2015b; Milledge and Harvey 2016a). The Consortium for Algal Biofuel Commercialisation (CAB-Comm), established to conduct research to enable commercial viability of alternative liquid fuels produced from algal biomass, found in a sensitivity analysis that increasing $\mathrm{CH}_{4}$ yield from the anaerobic digestion of seaweed was the most important factor in improving process energy balance and reducing greenhouse gas emissions (Mayfield 2015); thus, further research on the factors reducing practical methane yields is vital.

There is considerable conjecture about the reasons for the relatively low practical methane yields from seaweed compared to their theoretical values (Milledge et al. 2014; Sutherland and Varela 2014; Ward et al. 2014; Soto et al. 2015b; Tabassum et al. 2016). However, polyphenols are suggested as one of the elements in the low yield of methane from brown seaweeds (Hierholtzer et al. 2013; Ward et al. 2014; Barbot et al. 2016; Pérez et al. 2016; Tabassum et al. 2016). Phenols are a diverse group of compounds that have a hydroxyl group bonded to a benzene or benzenoid ring, and are widely distributed in plants and algae with $>8,000$ phenolic compounds being separated from terrestrial and marine organisms (Savithramma et al. 2014; Pérez et al. 2016). Tannins are an extremely heterogeneous group of phenolic compounds of particular interest in both plants and algae as they interact with 
aqueous solutions of proteins and other biological macromolecules to form insoluble precipitates (Holdt and Kraan 2011; Shannon and Abu-Ghannam 2016). They can be divided into 3 group; a) Hydrolysable tannins which on heating with hydrochloric or sulphuric acids yield gallic or ellagic acids; b) Non-hydrolysable tannins, oligomers or polymers of flavanol (Flavan-3-ols); and c) phlorotannins, polymers of phloroglucinol (1,3,5-benzenetriol) which are found primarily in seaweeds (Holdt and Kraan 2011; Daglia 2012; Farvin and Jacobsen 2013; Tanniou et al. 2013; Soto et al. 2015a; Sanchez-Camargo et al. 2016). Phenolic compounds are believed to damage microbial cells by altering membrane permeability, causing leakage of intracellular components and inactivation of essential enzymatic systems, with lower molecular weight phenolics beings more toxic to microorganisms than high molecular weight compounds (Monlau et al. 2014). A few phenolic extracts from $S$. muticum have shown antimicrobial activity against some aerobic bacteria (Tanniou et al. 2014). However, there are few reports on the characterisation of polyphenols from algae, although both Glombitza et al. (1982) and Montero et al. (2016) have identified some of the phenolics present in S. muticum. Tabassum et al. (2016) found an association between the high phenolic content in Ascophyllum nodosum and reduced methane yields, and Moen et al. (1997) found that biogas production was improved in Ascophyllum nodosum when polyphenols were 'fixed' by formaldehyde. However, there appears to be little information on the effect of specific phenolics on defined substrates; thus, this paper attempts to examine the effect of some simple representative phenolic compounds on methane production from a range of substrates.

\section{Materials and methods}

Three simple phenolics were selected to each represent a hydrolysable phenolic, a nonhydrolysable phenolic and a phlorotannin. Gallic acid has been found to be present in a number of different seaweeds including Sargassum, and is the most common standard for total phenolic analysis (Rodríguez-Bernaldo de Quirós et al. 2010; Farvin and Jacobsen 2013; Kang et al. 2015; Klejdus et al. 2017). Catechin is a non-hydrolysable flavanol (flavan-3-ol) which has been used as a phenol standard (Rattaya et al. 2015; Wikandari et al. 2015). Both catechin and its epimeric-isomer epicatechin have been found in a range of brown seaweeds, with Sargassum muticum containing $2620 \mu \mathrm{g} \mathrm{g}^{-1} \mathrm{dw}$ of epicatechin, although no catechin was found (Yoshie et al. 2000; Fernando et al. 2016); thus, epicatechin was selected as model simple non-hydrolysable phenolic. Phloroglucinol is the basis of phlorotannins, the predominant polyphenol in many seaweeds and Sargassum muticum (Glombitza et al. 1982; Holdt and Kraan 2011; Moorthi and Balasubramanian 2015; Montero et al. 2016), and a standard for total phlorotannin analysis (Tanniou et al. 2014; Sanchez-Camargo et al. 2016); therefore, phloroglucinol was selected as the third model phenolic.

Brown seaweed can contains high levels of phenolics with levels of $14 \%$ dw being reported for some species (Holdt and Kraan 2011). Sargassum muticum can contain $>6 \% \mathrm{dw}$ polyphenols (Gorham and Lewey 1984; Connan et al. 2006), with Tanniou et al. (2014) reporting values of $0.7-3.5 \%$ for $S$. muticum sampled along its European range from Norway to Portugal. Four phenolic addition levels were used $0,0.5,3.5$ and $7.5 \%$ of the substrate to cover the potential concentration range of phenolic compounds in S. muticum and the inhibitory effect of phenolics on methane production from AD.

Four substrates were used, a readily digested simple organic substance, glycerol, and three polymers found in seaweed, cellulose, alginic acid and the sodium salt of alginic acid. 
Glycerol is readily broken down in AD to produce biogas, and 'waste' glycerol has been considered as both a substrate and co-substrate with S. muticum for AD (Viana et al. 2012; Oliveira et al. 2015; Milledge and Harvey 2016a). Alginates are a major component of the cell-wall of brown algae accounting for up to $40 \%$ of the dry weight (Jung et al. 2013), most commonly as cationic salts containing either sodium, calcium and magnesium (Kaplan 1998; Rehm 2009; Holdt and Kraan 2011). Brown algae have carbohydrate-rich cell-walls with the 2 main polysaccharides being alginates and sulphated polysaccharides. The sulphated polysaccharides crosslink with cellulose microfibrils, while the alginates are associated with phenolic compounds to form a network in which the cellulose and sulphated carbohydrates are embedded. Cell wall rigidity is controlled by alginate structure and polyphenol crosslinking (Salmeán et al. 2017). The hydrolysis of seaweed-derived polysaccharides, particularly alginates, is considered the rate-limiting step in the $\mathrm{AD}$ of seaweed (Moen et al. 1997; Sutherland and Varela 2014).

The methane potential was measured for 12 combinations of substrate (glycerol, alginic acid sodium salt (sodium alginate), alginic acid and cellulose) and phenolic (gallic acid, phloroglucinol and epicatechin) for 4 levels phenolic addition $0,0.5,3.5$ and $7 \%$ of the mass of the substrate.

\subsection{Materials}

Substrates

a) Glycerol - reagent grade Fisher Scientific CAS No. 56-81-5

b) Cellulose - Sigmacell cellulose powder Type $2020 \mu \mathrm{m}$ Sigma CAS No. 9004-34-6

c) Alginic Acid sodium salt (sodium alginate) - Aldrich CAS No. 9005-38-3

d) Alginic Acid - Acros organics CAS No. 9005-32-7 Phenolics

a) Gallic Acid - 97.5 - 102.5 titration Sigma CAS No. 149-91-7

b) Phloroglucinol - $\geq 99.0 \%$ (HPLC) Aldrich CAS No 108-73-6

c) (-)Epicatechin- Sigma CAS No 490-46-0

\subsection{Methane potential determination}

Methane Potential (MP) was analysed using an automatic methane potential test system (AMPTS II, Bioprocess Control, Sweden). The equipment consists of a water-bath with controlled temperature and $15 \times 500 \mathrm{~mL}$ glass digestion bottles with $15 \mathrm{CO}_{2}$ fixing bottles, each one connected to one of the 15 digestion bottles and a tipping cup volumetric gas measuring device.

The $500 \mathrm{~mL}$ glass bottles were filled with inoculum, substrate and made-up to a volume of $400 \mathrm{~mL}$ with deionised water. The inoculum was collected from an internal recirculation granular sludge anaerobic digester treating papermaking liquid waste at Smurfit Kappa Townsend Hook Paper Makers, Mill Street, Snodland, Kent, UK, and stored for 48 hours at $37{ }^{\circ} \mathrm{C}$ to reduce gas output prior to use. The inoculum was blended using a handheld blender (Phillips Billy HR 1340/A) to give a consistent suspension immediately prior to use. The ash and CHNOS analysis of the inoculum solids was $31.85 \%$ ash, $33.36 \% \mathrm{C}, 4.85 \% \mathrm{H}, 24.01 \%$ $\mathrm{O}, 5.46 \% \mathrm{~N}$ and $0.48 \% \mathrm{~S}$ of the dry weight (Milledge and Harvey 2016a).Three experimental replicates using $1 \mathrm{~g}$ of model substrate with an inoculum-to-substrate ratio on a volatile solid basis of 9:1 were carried out, together with a control containing inoculum, but no additional substrate. 
After filling and sealing of the digestion bottles, the headspace was flushed with nitrogen. Bottles were incubated in a water bath at a mesophilic temperature of $37^{\circ} \mathrm{C}$ for 28 days. The content of each bottle was mixed throughout the test by a slowly rotating agitator at $30 \mathrm{rpm}$, operating for $60 \mathrm{~s}$ at a time interval of $60 \mathrm{~s}$. Biogas from each digester was passed through fixing bottles containing $80 \mathrm{~mL}$ of $3 \mathrm{M} \mathrm{NaOH}$ solution (containing thymolphthalein indicator) for fixation of carbon dioxide, and the resultant methane subsequently measured in a tipping cup volumetric gas measuring device submerged in deionised water. Methane volume and temperature data were recorded continuously, and volumes were normalised to standard conditions (standard atmospheric pressure, $0{ }^{\circ} \mathrm{C}$, dry gas).

The $\mathrm{pH}$ was measured (Hauna Instruments HI221) for each sample at end of the MP test.

\subsection{Statistical Analysis}

IBM SPSS Statistics 23 was used for three-way and two-way Analysis of and Variance (ANOVA) with data tests for Skewness (0.5 to -0.5)), Kurtosis (1 to -1) and normality (Kolmogorov-Smirnov (>0.05) and Shapiro-Wilks (>0.05)). A three-way ANOVA was performed to compare the effect of substrate (4 variants), potential phenolic inhibitor (3 variants) and potential phenolic inhibitor concentration (4 variants) and their high order interactions on final total methane production from the MP test. A series of 3 two-way ANOVAs were performed for each phenolic examining the effect of substrate (4 variants), and potential phenolic inhibitor concentration (4 variants) and their high order interactions on final total methane production from the MP test.

Excel 2013 (Microsoft) was used for one-way ANOVA and all other statistical analyses. A one-way ANOVA was conducted to compare the effect of phenolic concentration on final total methane production after MP test and $\mathrm{pH}$ for each of the 12 combinations of substrate and potential phenolic inhibitor.

\section{Results}

\section{$3.1 \mathrm{pH}$}

The $\mathrm{pH}$ varied little across the range of experiments as shown in Table1. There was no statistically significant effect $(\mathrm{P}<0.05)$ of phenolic concentration in any of the 12 combinations of phenolic and substrate.

\subsection{Methane production}

The final methane yields from the 28 day MP test for the range of substrate and phenolic concentrations are shown in Table 2.

A one-way ANOVA, for each of the 12 combinations of substrate and potential phenolic inhibitor, for the effect of phenolic concentration on final total methane production after MP test, found that phenolic concentration was only significant for one combination of substrate and phenolic, epicatechin and alginic acid (highlighted by bold type and the superscript ${ }^{\#}$ ). However, student t-tests of the final total methane production for the lowest $(0 \%)$ and highest (7\%) phenolic concentrations for each of the 12 combinations of substrate and phenolic showed that for both the cellulose and gallic acid combination and the alginic acid sodium salt and phloroglucinol combination the final total methane production was significantly 
lower $(\mathrm{P}<0.05)$ for the highest phenolic concentration relative to the lowest $(0 \%)$ (highlighted by the superscript $*)$.

The three-way ANOVA comparing the effect of substrate (4 variants), potential phenolic inhibitor (3 variants) and potential phenolic inhibitor concentration (4 variants) and their high order interactions on final total methane production from the MP test showed that substrate, phenolic and the interaction of substrate and phenolic all had a highly significant effect $(\mathrm{P}<0.01)$ on final methane yield.

The series of 3 two-way ANOVAs for each phenolic examining the effect substrate (4 variants), potential phenolic inhibitor concentration (4 variants) and their high order interactions on final total methane production from the MP test also found that the effect of substrate on final methane yield was highly significant $(\mathrm{P}<0.01)$

The grand means (average mean) for the final methane yields for the four substrates without the addition of phenolic are shown in Table 3, and illustrate that highest gas yields were achieved with glycerol or cellulose as substrates.

\section{Discussion}

The substrate is a dominant factor in methane potential. Alginic acid and its sodium salt appear to be recalcitrant with average methane yields of 73 and $76 \mathrm{~mL} \mathrm{CH}_{4} \mathrm{~g}^{-1}$ substrate dw, equivalent to only $23 \%$ and $28 \%$ of their theoretical methane potential as calculated from elemental compositions $\left(\left(\mathrm{C}_{6} \mathrm{H}_{8} \mathrm{O}_{6}\right)_{\mathrm{n}}\right.$ and $\left.\left(\mathrm{C}_{6} \mathrm{H}_{7} \mathrm{NaO}_{6}\right)_{\mathrm{n}}\right)$ using the "Buswell equation" (Symons and Buswell 1933; Buswell and Mueller 1952; Heaven et al. 2011). Østgaard et al. (1993) found mannitol and laminaran were reduced to less than $5 \%$ of the initial values within 24-48 hours in an anaerobic digester, but over $30 \%$ of the alginate content remained after 30 days. Moen et al. (1997) found that the successful biological degradation of A. nodosum was dependant on the breakdown of alginate, and the hydrolysis of seaweed-derived polysaccharides, particularly alginates, is considered the rate-limiting step in the AD of seaweed (Moen et al. 1997; Sutherland and Varela 2014). Sodium alginate has been shown to be an anti-bacterial element not only binding to bacteria, but also killing them (Kraan 2012). The methane potential of $S$. muticum is $0.06-0.13 \mathrm{~L} \mathrm{CH}_{4} \mathrm{~g}^{-1} \mathrm{VS}, 16-27 \%$ of that calculated by the "Buswell" equation from the ultimate analysis (Jard et al. 2013; Soto et al. 2015b; Milledge and Harvey 2016a). S. muticum has been used for alginate production (Zhao et al. 2008; Liu et al. 2013), with a yield of 5-11\% (Critchley et al. 1986; Gonzalez-Lopez et al. 2012), and thus one factor in the low yield of methane from $S$. muticum could be the recalcitrance of the alginates.

One approach to improving biogas may be to treat the seaweed prior to anaerobic digestion to break down recalcitrant polymers, such as alginic acid, to more readily digested simple molecules A variety of pre-treatment methods for biomass disruption, such as mechanical, thermal, enzymatic and thermo-chemical treatment, have been shown to improve methane production by $19 \%$ - 68\% (Barbot et al. 2015). However, the energy and financial costs of these procedures may offset any potential gain from increased biogas output (Barbot et al. 2016). A biorefinery approach where alginates are removed prior to biogas production is another potential method of improving the economics of seaweed biogas production (Langlois et al. 2012; Milledge et al. 2014). The extraction of alginate, laminaran and fucoidan can reduce the amount of fermentable compounds available in seaweed to produce 
bioenergy by half (Bruton et al. 2009), but the biomass from a range Irish seaweeds after the extraction of alginic acid and other potential high-value commercial compounds were found to have a similar methane yield per gram of volatile solid to that of the original seaweed (Tedesco and Stokes 2017). However, the economic success of a biorefinery producing alginates and biogas is highly dependent on the price of alginate (Langlois et al. 2012). The immense potential scale of algal fuel production could result in the creation of such large quantities of algal non-fuel materials that the market price is dramatically reduced (Milledge and Heaven 2014). Bruton et al. (2009) have suggested that the world market growth for phycocolloids is only a few percent per year and that any large additional supply could rapidly saturate the market.

Alginates are used in the marine environment by organisms that have alginate lyases, found in some marine molluscs, fungi and bacteria, but generally absent from most organisms (Østgaard et al. 1993). Typical inocula for anaerobic digesters are from municipal sewage sludge and animal manure slurry, but inocula containing higher proportions of bacteria capable of fermenting marine phycocolloids have been shown to increase methane production (Sutherland and Varela 2014). The addition of bacteria from the rumen of Ronaldsay sheep, which had a diet almost entirely of seaweed, was found to increase the methane yield $(0.253$ $\mathrm{L} \mathrm{CH}_{4} \mathrm{~g}^{-1} \mathrm{VS}$ ) and volatile solid utilisation (67\%) from the anaerobic digestion of Laminaria hyperborean (Sutherland and Varela 2014). The granulated sludge inoculum from paper waste treatment, which was effective in the anaerobic breakdown of cellulose (a major part of paper waste), may not be ideal for seaweed, but inocula containing bacteria capable of fermenting marine phycocolloids, such as those from Ronaldsay sheep, are not currently widely available.

The three-way ANOVA found that the phenolic and the interaction of substrate and phenolic all had a highly significant effect $(\mathrm{P}<0.01)$ on final methane yield. Different phenolics appear to interact with different substrates reducing methane yield.

Concentrations of $7 \%$ gallic acid, equivalent to $17.5 \mathrm{mg} \mathrm{L}^{-1}$, significantly reduced methane yield from cellulose by $34 \%$. Gallic acid at a concentration of $10 \mathrm{mg} \mathrm{L}^{-1}$ has been shown to inhibit biogas production from starch by up to $75 \%$ (Mousa and Forster 1999). Gallic acid, thus, may be a phenolic inhibitor of starch and cellulose digestion, and plays a role in the reduction of methane production from seaweeds where cellulose can make up 7-30\% of the dry weight of seaweed depending on species (Tiwari and Troy 2015). High levels of gallic acid could also be important inhibitors in biomass from terrestrial crop residues that contain significant amounts of cellulose.

Concentrations of $7 \%$ phloroglucinol equivalent to $17.5 \mathrm{mg} \mathrm{L}^{-1}$ significantly reduced methane yield from the sodium salt of alginic acid to such an extent the methane yield was below the yield from the inoculum alone without substrate. Although not statistically significant, the presence of $7 \%$ phloroglucinol also reduced average methane yield $>50 \%$ from alginic acid. Methane yield from $\mathrm{AD}$ of $A$. nodosum was found to increase when the polyphenols present were fixed with low levels of formaldehyde, and polyphenols may be inhibiting alginate lyases (Moen et al. 1997). Hierholtzer et al. (2013) found that there was no significant effect from the presence phloroglucinol or phlorotannins extracted from $L$. digitata (2-200 $\left.\mathrm{mg} \mathrm{L}^{-1}\right)$ on the methane production from the $\mathrm{AD}$ of a model sodium acetate substrate. However, at the very highest concentration of phlorotannins $\left(200 \mathrm{mg} \mathrm{L}^{-1}\right)$ there was 
a $20 \%$ reduction in methane yield, and scanning electron micrographs found that at this concentration there was damage to the cell wall of the anaerobic bacteria in the digester. Low molecular weight phlorotannins from Sargassum thunbergii have also been found to damage the cell walls and membranes of gram negative bacteria (Shannon and Abu-Ghannam 2016). Phloroglucinol is the basis of phlorotannins, the predominant polyphenol in many seaweeds including $S$. muticum, and at high concentration may be an additional element, together with the recalcitrance of alginic acid, in the low methane production from many brown seaweeds and S. muticum. Nevertheless, the mode of action of phlorotannins on anaerobic microorganisms remains obscure and there is little information available regarding their influence on mixed microbial cultures found in anaerobic digesters (Hierholtzer et al. 2013), and there is a need for considerable research on the influence of phlorotannins on the various bacterial types involved in anaerobic digestion.

The concentration of epicatechin was found to have a statistically significant effect on methane yield from alginic acid; a $7 \%$ concentration of epicatechin, equivalent to $17.5 \mathrm{mg}$ $\mathrm{L}^{-1}$, reducing methane yield by $73 \%$. Wikandari et al. (2015) found that very high levels of epicatechin $5 \mathrm{~g} \mathrm{~L}^{-1}$ inhibited the methane production from a beef extract model substrate by $>90 \%$, but that lower levels $0.5 \mathrm{~g} \mathrm{~L}^{-1}$ had no statistically significant effect. A phenolic concentration of $54 \mathrm{mg} \mathrm{L}^{-1}$ has been shown to reduce methane yields from olive oil production waste by $\sim 35 \%$ (Battista et al. 2014). Very high concentrations of epicatechin may inhibit methane production from both terrestrial plants and seaweeds.

None of the phenolic compounds studied appeared to inhibit the breakdown of the simple and readily digested compound, glycerol. Indicating that phenolic compounds probably inhibit the breakdown of more complex molecules in the initial hydrolysis stage of anaerobic digestion. Co-digestion of glycerol and S. muticum increased the biogas yield by $27 \%$ when compared to the individual materials digested separately (Milledge and Harvey 2016a). A further potential explanation of this synergistic effect in co-digestion of glycerol and S. muticum could be the reduction in the level of phlorotannins and their inhibitory effect on the breakdown of alginates.

This work has shown that a major contributor to the low methane yield is the recalcitrance of alginic acid and its sodium salt. High concentrations (7\% of substrate equivalent to $17.5 \mathrm{mg}$ $\mathrm{L}^{-1}$ ) of epicatechin further reduce methane yield from alginic acid, whilst high concentrations of phloroglucinol reduce the methane yield from the sodium salt of alginic acid. This study only assessed single phenolic compounds, and in real systems, there are mixtures of phenols. López et al. (2011) have suggested that mixtures of phenolic can act either synergistically or antagonistically. Further work is required to study other phenolic compounds derived from seaweeds and their action and interaction on biogas production and the bacteria and their biochemical pathways.

\section{Acknowledgements}

This work was supported by the EPSRC project number EP/K014900/1 (MacroBioCrude: Developing an Integrated Supply and Processing Pipeline for the Sustained Production of Ensiled Macroalgae-derived Hydrocarbon Fuels) and the University of Greenwich. The assistance of colleagues at the University of Greenwich, and Smurfit Kappa Townsend Hook Paper Makers for the provision of the inoculum. 


\section{References}

Alvarado-Morales M, Boldrin A, Karakashev DB, Holdt SL, Angelidaki I, Astrup T (2013) Life cycle assessment of biofuel production from brown seaweed in Nordic conditions. Bioresour Technol 129:92-99

Astals S, Musenze RS, Bai X, Tannock S, Tait S, Pratt S, Jensen PD (2015) Anaerobic co-digestion of pig manure and algae: Impact of intracellular algal products recovery on co-digestion performance. Bioresour Technol 181:97-104

Balboa E, Moure A, Domínguez H (2015) Valorization of Sargassum muticum biomass according to the Biorefinery Concept. Mar Drugs 13:3745

Banks C, Zhang Y (2010) Optimising inputs and outputs from anaerobic digestion processes - Technical Report. DEFRA, Southampton

Barbot Y, Al-Ghaili H, Benz R (2016) A review on the valorization of macroalgal wastes for biomethane production. Mar Drugs 14:120

Barbot Y, Thomsen C, Thomsen L, Benz R (2015) Anaerobic digestion of Laminaria japonica waste from industrial production residues in laboratory- and pilot-scale. Mar Drugs 13:5947

Battista F, Fino D, Ruggeri B (2014) Polyphenols concentration's effect on the biogas production by wastes derived from olive oil production. Chem Eng Trans 38:373-377

Biomara (2014) A short history of seaweed exploitation in the western British Isles http://www.biomara.org/understanding-seaweed/the-importance-of-seaweed-across-the-ages. Searched 27 January 2014

Bruton T, Lyons H, Lerat Y, Stanley M, Rasmussen MB (2009) A review of the potential of marine algae as a source of biofuel in Ireland. Sustainable Energy Ireland, Dublin

Buswell AM, Mueller HF (1952) Mechanism of methane fermentation. Ind \& Eng Chemistry 44:550-552

Cave S (2013) Anaerobic digestion across the UK and Europe. Northern Ireland Assembly, Belfast

Centre for Process Innovation (CPI) (2016) The SeaGas project. CPI. http://seagas.co.uk/. Searched 7 July 2016

Chen H, Zhou D, Luo G, Zhang S, Chen J (2015) Macroalgae for biofuels production: Progress and perspectives. Renew Sust Energy Rev 47:427-437

Connan S, Delisle F, Deslandes E, Gall EA (2006) Intra-thallus phlorotannin content and antioxidant activity in Phaeophyceae of temperate waters. Botanica Marina 49:39-46

Critchley AT, Farnham WF, Morrell SL (1986) An account of the attempted control of an introduced marine alga, Sargassum-muticum, in southern England. Biol Conserv 35:313-332

Daglia M (2012) Polyphenols as antimicrobial agents. Curr Opin Biotechnol 23:174-181

Dijk Wv, Schoot JRvd (2015) An economic model for offshore cultivation of macroalgae. EnAlgae project, Swansea

Discover Tiree (2014) Brown Gold. http://www.isleoftiree.com/about-tiree/the-land/. Searched 27 January 2014

Farvin KHS, Jacobsen C (2013) Phenolic compounds and antioxidant activities of selected species of seaweeds from Danish coast. Fd Chem 138:1670-1681

Fernando IP, Kim M, Son KT, Jeong Y, Jeon YJ (2016) Antioxidant activity of marine algal polyphenolic compounds: A mechanistic approach. J Medicinal Fd 19:615-628

Glombitza KW, Forster M, Farnham WF (1982) Antibiotics from algae .25. Polyhydroxyphenyl ethers from the brown alga Sargassum muticum (yendo) fensholt 2. Botanica Marina 25:449-453

Golueke CG, Oswald WJ, Gotaas HB (1957) Anaerobic digestion of algae. Appl Microbiol 5:47-55

Gonzalez-Lopez N, Moure A, Dominguez H (2012) Hydrothermal fractionation of Sargassum muticum biomass. J Appl Phycol 24:1569-1578

Gorham J, Lewey SA (1984) Seasonal changes in the chemical composition of Sargassum muticum. Marine Biol 80:103-107

Heaven S, Milledge JJ, Zhang Y (2011) Comments on 'Anaerobic digestion of microalgae as a necessary step to make microalgal biodiesel sustainable'. Biotechnol Adv 29: 164-167 doi:DOI:

Hierholtzer A, Chatellard L, Kierans M, Akunna JC, Collier PJ (2013) The impact and mode of action of phenolic compounds extracted from brown seaweed on mixed anaerobic microbial cultures. J Appl Microbiol 114:964-973

Holdt S, Kraan S (2011) Bioactive compounds in seaweed: functional food applications and legislation. J Appl Phycol 23:543-597

Jard G, Marfaing H, Carrere H, Delgenes JP, Steyer JP, Dumas C (2013) French Brittany macroalgae screening: Composition and methane potential for potential alternative sources of energy and products. Bioresour Technol 144:492-498 
Josefsson M, Jansson K (2011) NOBANIS - Invasive alien species fact sheet - Sargassum muticum. http://www.nobanis.org/files/factsheets/Sargassum_muticum.pdf. Searched 4 April 2014

Jung KA, Lim SR, Kim Y, Park JM (2013) Potentials of macroalgae as feedstocks for biorefinery. Bioresour Technol 135:182-190

Kang N et al. (2015) Gallic acid isolated from Spirogyra sp. improves cardiovascular disease through a vasorelaxant and antihypertensive effect. Environ Toxicol Pharmacol 39:764-772

Kaplan D (1998) Biopolymers from renewable resources. Springer-Verlag, Berlin.

Klejdus B, Plaza M, Śnóblová M, Lojková L (2017) Development of new efficient method for isolation of phenolics from sea algae prior to their rapid resolution liquid chromatographic-tandem mass spectrometric determination. J Pharm Biomed Anal 135:87-96

Kraan S (2012) Algal polysaccharides, novel applications and outlook. In: Chang C-F (ed) Carbohydrates comprehensive studies on glycobiology and glycotechnology. vol 22. InTech, Rijeka, Croatia.

Langlois J, Sassi JF, Jard G, Steyer JP, Delgenes JP, Helias A (2012) Life cycle assessment of biomethane from offshore-cultivated seaweed. Biofuels Bioprod Biorefining 6:387-404

Lewis J, Salam F, Slack N, Winton M, Hobson L (2011) Product options for the processing of marine macroalgae - Summary Report. The Crown Estates, Redcar.

Linville JL, Shen Y, Wu MM, Urgun-Demirtas M (2015) Current state of anaerobic digestion of organic wastes in North America. Curr Sust/Renew Energy Rep 2:136-144

Liu F, Pang SJ, Gao SQ, Shan TF (2013) Intraspecific genetic analysis, gamete release performance, and growth of Sargassum muticum (Fucales, Phaeophyta) from China. Chin J Ocean Limnol 31:1268-1275

López A, Rico M, Rivero A, Suárez de Tangil M (2011) The effects of solvents on the phenolic contents and antioxidant activity of Stypocaulon scoparium algae extracts. Fd Chem 125:1104-1109

Lou XF, Nair J, Ho G (2013) Potential for energy generation from anaerobic digestion of food waste in Australia waste management \& research. J Int Solid Wastes Public Cleansing Assoc, ISWA 31:283294

Mayfield SP (2015) Consortium for Algal Biofuel Commercialization (CAB-COMM) Final Report. Cal-CAB San Diego.

Menetrez M (2012) An overview of algae biofuel production and potential environmental impact. Environ Sci Technol 46: 7073-85

Milledge JJ, Harvey PJ (2016a) Ensilage and anaerobic digestion of Sargassum muticum. J Appl Phycol 28:3021-3030

Milledge JJ, Harvey PJ (2016b) Potential process 'hurdles' in the use of macroalgae as feedstock for biofuel production in the British Isles. J Chem Technol Biotechnol 91:2221-2234

Milledge JJ, Heaven S (2014) Methods of energy extraction from microalgal biomass: a review. Rev Environ Sci Biotechnol 13:301-320

Milledge JJ, Nielsen BV, Bailey D (2015a) High-value products from macroalgae: the potential uses of the invasive brown seaweed, Sargassum muticum. Rev Environ Sci Biotechnol 15:67-88

Milledge JJ, Smith B, Dyer P, Harvey P (2014) Macroalgae-derived biofuel: a review of methods of energy extraction from seaweed biomass. Energies 7:7194-7222

Milledge JJ, Staple A, Harvey P (2015b) Slow pyrolysis as a method for the destruction of Japanese Wireweed, Sargassum muticum. Environ Nat Resour Res 5:28-36

Moen E, Horn S, Østgaard K (1997) Biological degradation of Ascophyllum nodosum J Appl Phycol 9:347-357

Monlau F, Sambusiti C, Barakat A, Quéméneur M, Trably E, Steyer JP, Carrère H (2014) Do furanic and phenolic compounds of lignocellulosic and algae biomass hydrolyzate inhibit anaerobic mixed cultures? A comprehensive review. Biotechnol Adv 32:934-951

Montero L et al. (2016) Anti-proliferative activity and chemical characterization by comprehensive twodimensional liquid chromatography coupled to mass spectrometry of phlorotannins from the brown macroalga Sargassum muticum collected on North-Atlantic coasts. J Chromatogr A 1428:115-125

Moorthi PV, Balasubramanian C (2015) Antimicrobial properties of marine seaweed, Sargassum muticum against human pathogens. J Coast Life Medicine 3:122-125

Mousa L, Forster CF (1999) The use of trace organics in anaerobic digestion. Process Saf Environ Prot 77:37-42

Nallathambi Gunaseelan V (1997) Anaerobic digestion of biomass for methane production: a review. Biomass Bioenergy 13:83-114

Nguyen H, Heaven S, Banks C (2014) Energy potential from the anaerobic digestion of food waste in municipal solid waste stream of urban areas in Vietnam. Int J Energy Environ Eng 5:365-374

Oliveira JV, Alves MM, Costa JC (2015) Optimization of biogas production from Sargassum sp. using a design of experiments to assess the co-digestion with glycerol and waste frying oil. Bioresour Technol 175:480-485 
Østgaard K, Indergaard M, Markussen S, Knutsen SH, Jensen A (1993) Carbohydrate degradation and methane production during fermentation of Laminaria saccharina (Laminariales, Phaeophyceae). J Appl Phycol 5:333-342

Pérez MJ, Falqué E, Domínguez H (2016) Antimicrobial action of compounds from marine seaweed. Mar Drugs 14:52

Rattaya S, Benjakul S, Prodpran T (2015) Extraction, antioxidative, and antimicrobial activities of brown seaweed extracts, Turbinaria ornata and Sargassum polycystum, grown in Thail. Int Aquat Res 7:1-16

Rehm BHA (ed) (2009) Alginates: biology and applications. Microbiology Monographs, vol 13. Springer, Heidelberg.

Rodrigues D et al. (2015) Chemical composition of red, brown and green macroalgae from Buarcos Bay in Central West Coast of Portugal. Fd Chem 183:197-207

Rodríguez-Bernaldo de Quirós A, Lage-Yusty MA, López-Hernández J (2010) Determination of phenolic compounds in macroalgae for human consumption. Fd Chem 121:634-638

Salmeán AA et al. (2017) Insoluble $(1 \rightarrow 3),(1 \rightarrow 4)-\beta$-D-glucan is a component of cell walls in brown algae (Phaeophyceae) and is masked by alginates in tissues. Sci Rep 7:2880

Sanchez-Camargo AD, Montero L, Stiger-Pouvreau V, Tanniou A, Cifuentes A, Herrero M, Ibanez E (2016) Considerations on the use of enzyme-assisted extraction in combination with pressurized liquids to recover bioactive compounds from algae. Fd Chem 192:67-74

Savithramma N, Linga Rao M, Venkateswarlu P (2014) Isolation and identification of phenolic compounds from Boswellia ovalifoliolata Bal. \& Henry and their free radical scavenger activity. Int J Drug Deliv Technol 4:14-21

Shannon E, Abu-Ghannam N (2016) Antibacterial derivatives of marine algae: an overview of pharmacological mechanisms and applications. Mar Drugs 14:81-104

Soto M, Falqué E, Domínguez H (2015a) Relevance of natural phenolics from grape and derivative products in the formulation of cosmetics. Cosmetics 2:259

Soto M, Vazquez MA, de Vega A, Vilarino JM, Fernandez G, de Vicente ME (2015b) Methane potential and anaerobic treatment feasibility of Sargassum muticum. Bioresour Technol 189:53-61

Sutherland A, Varela J (2014) Comparison of various microbial inocula for the efficient anaerobic digestion of Laminaria hyperborea. BMC Biotechnol 14:7

Symons GE, Buswell AM (1933) The methane fermentation of carbohydrates. J Am Chem. Soc 55:2028-2036

Tabassum MR, Xia A, Murphy JD (2016) Seasonal variation of chemical composition and biomethane production from the brown seaweed Ascophyllum nodosum. Bioresour Technol 216:219-226

Tanniou A et al. (2013) Green improved processes to extract bioactive phenolic compounds from brown macroalgae using Sargassum muticum as model. Talanta 104: 44-52

Tanniou A et al. (2014) Assessment of the spatial variability of phenolic contents and associated bioactivities in the invasive alga Sargassum muticum sampled along its European range from Norway to Portugal. J Appl Phycol 26:1215-1230

Tedesco S, Stokes J (2017) Valorisation to biogas of macroalgal waste streams: a circular approach to bioproducts and bioenergy in Ireland. Chemi Zvesti 71:721-728

Tiwari B, Troy D (eds) (2015) Seaweed sustainability: food and non-food applications. 1 edn. Academic Press, Amsterdam.

Viana MB, Freitas AV, Leitão RC, Pinto GAS, Santaella ST (2012) Anaerobic digestion of crude glycerol: a review. Environ Technol Rev 1:81-92

Ward AJ, Lewis DM, Green B (2014) Anaerobic digestion of algae biomass: a review. Algal Res 5:204-214

Weiland P (2010) Biogas production: current state and perspectives Appl Microbiol and Biotechnol 85:849-860

Wikandari R, Sari NK, A'Yun Q, Millati R, Cahyanto MN, Niklasson C, Taherzadeh MJ (2015) effects of lactone, ketone, and phenolic compounds on methane production and metabolic intermediates during anaerobic digestion. Appl Biochem and Biotechnol 175:1651-1663

Yoshie Y, Wang W, Petillo D, Suzuki T (2000) Distribution of catechins in Japanese seaweeds. Fish Sci 66:998-1000

Zhao FJ, Liu FL, Liu JD, Ang PO, Duan DL (2008) Genetic structure analysis of natural Sargassum muticum (Fucales, Phaeophyta) populations using RAPD and ISSR markers. J Appl Phycol 20:191-198 
Table 1 Effect of substrate and various concentrations $(0,0.5,3.5$ and $7 \%$ of substrate dry 540 weight) of Gallic acid, Phloroglucinol or Epicatechin on final $\mathrm{pH}$ after 28 day MP test.

541 (Average Ave, Standard Deviation SD, n=3)

\begin{tabular}{lcccccccr}
\hline $\begin{array}{l}\text { Phenolic \& Phenolic } \\
\text { Concentration }\end{array}$ & \multicolumn{7}{c}{ Substrate } \\
& \multicolumn{2}{c}{ Glycerol } & \multicolumn{7}{c}{$\begin{array}{c}\text { Alginic Acid } \\
\text { Sodium Salt }\end{array}$} & Alginic Acid & \multicolumn{2}{c}{ Cellulose } \\
\hline & Ave & SD & Ave & SD & Ave & SD & Ave & SD \\
\hline 0\% Gallic & 7.28 & 0.05 & 7.78 & 0.21 & 7.03 & 0.29 & 7.27 & 0.10 \\
\hline $0.5 \%$ Gallic & 7.11 & 0.01 & 7.42 & 0.28 & 7.05 & 0.16 & 7.23 & 0.06 \\
\hline 3.5\% Gallic & 7.23 & 0.15 & 7.25 & 0.34 & 7.22 & 0.11 & 7.32 & 0.09 \\
\hline 7.0\% Gallic & 7.27 & 0.10 & 7.42 & 0.25 & 7.16 & 0.17 & 7.40 & 0.06 \\
\hline & & & & & & & & \\
\hline $0 \%$ Phloroglucinol & 7.28 & 0.05 & 7.29 & 0.07 & 7.14 & 0.08 & 7.11 & 0.07 \\
\hline $0.5 \%$ Phloroglucinol & 7.11 & 0.01 & 7.34 & 0.15 & 7.18 & 0.07 & 7.05 & 0.01 \\
\hline $3.5 \%$ Phloroglucinol & 7.23 & 0.15 & 7.25 & 0.07 & 7.12 & 0.04 & 7.12 & 0.08 \\
\hline $7.0 \%$ Phloroglucinol & 7.27 & 0.10 & 7.39 & 0.10 & 7.20 & 0.09 & 7.08 & 0.06 \\
\hline & & & & & & & & \\
\hline $0 \%$ Epicatechin & 7.21 & 0.13 & 7.22 & 0.03 & 7.69 & 0.01 & 7.13 & 0.03 \\
\hline $0.5 \%$ Epicatechin & 7.21 & 0.14 & 7.25 & 0.02 & 7.72 & 0.02 & 7.11 & 0.01 \\
\hline $3.5 \%$ Epicatechin & 7.11 & 0.02 & 7.22 & 0.01 & 7.70 & 0.00 & 7.21 & 0.18 \\
\hline $7.0 \%$ Epicatechin & 7.20 & 0.15 & 7.20 & 0.02 & 7.89 & 0.19 & 7.10 & 0.01 \\
\hline
\end{tabular}


Table 2 Effect of substrate and various concentrations $(0,0.5,3.5$ and $7 \%$ of substrate dry weight) of Gallic acid, Phloroglucinol or Epicatechin on final average methane yield after 28 day MP test. (Average Ave, Standard Deviation SD, $\mathrm{n}=3$ ). Shaded figures are the $\mathrm{P}$ values from a one-way ANOVA conducted to compare the effect of phenolic concentration on final total methane production after 28 day MP test

\begin{tabular}{|c|c|c|c|c|c|c|c|c|}
\hline \multirow{2}{*}{$\begin{array}{l}\text { Phenolic \& Phenolic } \\
\text { Concentration }\end{array}$} & \multicolumn{8}{|c|}{ Substrate } \\
\hline & \multicolumn{4}{|c|}{$\begin{array}{r}\text { Alginic Acid } \\
\text { Sodium salt }\end{array}$} & \multicolumn{2}{|c|}{ Alginic Acid } & \multicolumn{2}{|c|}{ Cellulose } \\
\hline & \multicolumn{8}{|c|}{ Average Gas yield $\mathrm{mL} \mathrm{CH}_{4} \mathrm{~g}^{-1}$ substrate dw } \\
\hline & Ave & SD & Ave & SD & Ave & SD & Ave & SD \\
\hline 0 Gallic & 223 & 84 & 42 & 52 & 56 & 29 & 309 & 26 \\
\hline $0.5 \%$ Gallic & 186 & 114 & 59 & 34 & 38 & 51 & 306 & 33 \\
\hline $3.5 \%$ Gallic & 186 & 86 & 31 & 36 & 18 & 20 & 216 & 74 \\
\hline 7.0 Gallic & 223 & 113 & 68 & 23 & 63 & 66 & 203 & 33 \\
\hline $\mathrm{P}$ Value & 0.98 & & 0.74 & & 0.58 & & $0.07^{*}$ & \\
\hline $0 \%$ Phloroglucinol & 130 & 80 & 77 & 24 & 76 & 98 & 124 & 77 \\
\hline 0.5\% Phloroglucinol & 201 & 49 & 15 & 70 & 49 & 73 & 221 & 12 \\
\hline 3.5\% Phloroglucinol & 84 & 133 & 59 & 45 & 87 & 54 & 152 & 86 \\
\hline 7.0\% Phloroglucinol & 115 & 67 & -37 & 35 & 37 & 75 & 178 & 15 \\
\hline $\mathrm{P}$ value & 0.46 & & $0.07^{*}$ & & 0.84 & & 0.29 & \\
\hline $0 \%$ Epicatechin & 181 & 72 & 99 & 40 & 183 & 39 & 158 & 32 \\
\hline $0.5 \%$ Epicatechin & 208 & 48 & 126 & 35 & 218 & 5 & 183 & 3 \\
\hline $3.5 \%$ Epicatechin & 238 & 25 & 125 & 25 & 200 & 5 & 80 & 88 \\
\hline 7.0\% Epicatechin & 206 & 64 & 133 & 25 & 50 & 88 & 151 & 20 \\
\hline$P$ value & 0.68 & & 0.60 & & $0.01^{\#}$ & & 0.13 & \\
\hline
\end{tabular}


549 Table 3 Grand means for the final methane yields for the four substrates without the addition 550 of phenolic (Average Ave, Standard Deviation SD, n=12).

\begin{tabular}{|c|c|c|c|c|c|c|c|}
\hline \multicolumn{8}{|c|}{ Substrate } \\
\hline Glycerol & & $\begin{array}{l}\text { Alginic Acid } \\
\text { Sodium Salt }\end{array}$ & & Alginic Acid & & Cellulose & \\
\hline \multicolumn{8}{|c|}{ Average Gas yield $\mathrm{mL} \mathrm{CH}_{4} \mathrm{~g}^{-1}$ substrate $\mathrm{dw}$} \\
\hline Ave & SD & Ave & SD & Ave & SD & Ave & SD \\
\hline 178 & 75 & 76 & 40 & 73 & 54 & 183 & 92 \\
\hline
\end{tabular}

551

552 